\title{
WILL COVID-19 AFFECT THE QUALITY OF HUMAN DEVELOPMENT INDEX?
}

\author{
Suparmono \\ Staf Pengajar \\ Sekolah Tinggi Ilmu Manajemen YKPN Yogyakarta \\ e-mail : suparmono@stimykpn.ac.id
}

\begin{abstract}
This article aims to analyze the impact of Covid-19 on development, in particular, the quality of human development as measured by the human development index. The analysis is carried out using economic projections using the most appropriate projection approaches. From the analysis, it was found that the covid-19 that hit Kulon Progo Regency resulted in a decrease in the human development index. This decline brings the human development index to par with the conditions it was five years ago.
\end{abstract}

\begin{abstract}
ABSTRAK
Artikel ini bertujuan untuk menganalisis dampak Covid-19 terhadap pembangunan, khususnya kualitas pembangunan manusia yang diukur dengan indeks pembangunan manusia. Analisis dilakukan dengan menggunakan proyeksi ekonomi dengan menggunakan pendekatan proyeksi yang paling tepat. Dari hasil analisis diketahui bahwa COVID-19 yang melanda Kabupaten Kulon Progo mengakibatkan penurunan indeks pembangunan manusia. Penurunan ini membuat indeks pembangunan manusia sejajar dengan kondisi lima tahun lalu.
\end{abstract}

Kata Kunci : Indeks pembangunan manusia, covid-19, ekonomi regional, trend.

\section{INTRODUCTION}

On 31 December 2019, the headquarters of the World Health Organization (WHO), in China, was notified of cases of pneumonia, of uncertain etiology, identified in the city of Wuhan, Hubei province. On January 7, 2020, a new form of coronavirus was isolated and new cases have been identified in Thailand, Vietnam, Japan, and South Korea. On 30 January 2020, the WHO announced an appearance of universal public health(Maciel, Castro-Silva, and de Farias 2020). How to quantitatively evaluate sustainable development has become a hot topic. Frequently used for the quantification of environmental impacts become environmentally relate footprints (Long et al. 2020). Nowadays, the rapid economic growth heavily promotes the development of a country or region. People pay more

attention to the development of economic growth, which is the focus of society. Therefore, it is very important to study the influences of economic growth from different angles nowadays (Xu and $\mathrm{Li} 2020$ ).

Recent transformations in development discourse have been in the direction of moving away from productive systems while focusing essentially on the goals of development, be it the Millennium Development Goals, the Sustainable Development Goals, and other goals connected to the measurement of human well-being (Martins 2020).

An increasing number of studies argue that human capital (HC) has become a key factor in economic development (Yang and Pan 2020). Human development occurs through reciprocal coactions between the individual and their contexts and culture, with relationships as the key 
drivers. Relationships and contexts, along with how children appraise and interpret them, can be risks and assets for healthy learning and development, and their influence can be seen across generations and can produce as well as intergenerational assets and risks (Osher et al. 2020). An important rule of the epidemiological transition of a particular disease is that it starts from the rich provinces, districts, locations, and high socioeconomic status (SES) individuals and then gradually permeates down to middle SES and finally comes to rest among the low SES people in low SES locations (Gupta, Dhamija, and Gaur 2020).

Assessing human development should be more directly linked to the freedom to choose from available opportunities, rather than to possessions and income that do not capture the complete array of human experience dimensions (Croes, Ridderstaat, and Shapoval 2020).

\section{THEORETICAL REVIEW}

Although most empirical evidence demonstrates that financial development has a positive long-run impact on economic growth, there is no consensus in both theoretical and empirical evidence on the effect of financial structure on economic growth (Chu 2020). Economic growth is inseparable from the role of quality human resources at the most suitable time and place (Chu 2020). They also find that more unequal societies tend to redistribute more, but that redistribution does not have a major effect on economic growth. In their baseline regressions, they include initial income, inequality, and redistribution. They add standard growth determinants such as investment, population growth, and education to verify if their results hold with a wider set of control variables (Breunig and Majeed 2020).

The quality of human resources is also determined by economic capacity as measured by the level of income. Thus as usual the impact has addressed immediately the poor whose food security is at the lowest level and then the middle-income earners. A potential cure, control, or vaccine is far beyond imagination and the period with the present situation to continue is unpredictable as yet(Ranasinghe, Karunarathna, and Pradeepamali 2020). In addition to economic capacity, the quality of human resources will also be influenced by this human ability to innovate, where innovation will ultimately increase income (Maradana et al. 2019).

A lockdown implies that some activities -like healthcare or food chain-related jobswill become essential while others will be closed. When the occupation is essential, workers will be not affected by lockdown regardless of their capacity to work from home. When a certain economic activity is closed -like hospitality- working is not at all possible, and teleworking does not matter. For the remaining economic activities, only teleworking is allowed. Consequently, during the lockdown we need to adjust our index of teleworking for the workers whose occupation is essential or closed, to obtain an individual measure that summarizes the capacity of each worker to keep active under the lockdown (Palomino, Rodriguez, and Sebastian 2020).

\section{METHODOLOGY}

This method of research is useful for projecting the macroeconomic metrics, particularly the Kulon Progo Regency human development index using pattern analysis. The data used in the analysis during the period 2014-2019, which forecasts for macroeconomic project variables for the period 2020-2024, which is useful to the government in deciding economic policies to foster inclusiveness.

Alternative Forecasting Methods With Time Trends.

(1) Linear $Y t=\beta 0+\beta 1 T$

(2) Logarithmic $Y t=\beta 0+\beta 1 \ln (\mathrm{T})$ 
(3) Inverse $\mathrm{Yt}=\beta 0+\beta 1 / \mathrm{T}$

(4) Quadratic $Y t=\beta 0+\beta 1 \mathrm{~T}+\beta 2 \mathrm{~T} 2$

(5) Cubic $\mathrm{Yt}=\beta 0+\beta 1 \mathrm{~T}+\beta 2 \mathrm{~T} 2+\beta 3 \mathrm{~T} 3$

(6) Compound $\mathrm{Yt}=\beta 0 \beta 1 \mathrm{~T}$

(7) Power $Y t=\beta 0 T \beta 1$

(8) $\mathrm{S} \mathrm{Yt}=\mathrm{e}(\beta 0+\beta 1 / \mathrm{T})$

(9) Growth $Y t=e(\beta 0+\beta 1 T)$

(10) Exponential $\mathrm{Yt}=\beta 0 \mathrm{e} \beta 1 \mathrm{~T}$

(11) Logistic $\mathrm{Yt}=(1 / \mathrm{u}+\beta 0 \beta 1 \mathrm{~T})-1$

Note: $\mathrm{Yt}=$ Variable predicted; $\mathrm{T}=$ Year; $\mathrm{ln}=$ natural logarithm;

$\mathrm{e}=$ number 2.718282; $\mathrm{u}=$ upper bound value (upperbound) used in the logistic regression equation.

The upper bound specification is positive, and the dependent variable must be greater than the largest data value. The default value for upper bound is infinity, so $1 / \mathrm{u}=0$ and is excluded from the logistic equation. If an upper bound value is not reached, we define the upper bound with an infinite value.

\section{RESULT AND DISCUSSION}

One of the efforts to increase the standard of living and welfare of the population to achieve prosperity is the goal of economic development. The concept of economic development focuses more on efforts to increase economic growth and equity. One of the important achievements in a sound economic development process is the increase in the Human Development Index (HDI). HDI is an indicator used to see and measure the degree of development of human quality in an area. The human development paradigm is the result of a long process of the development concept itself. Previously, development focused on production, then shifted to the distribution of development results. After that, it shifted again to meeting the basic needs of society, until finally towards a development paradigm that focuses on human development that emerged in the 1990s.

In 2020, the RLS of Kulon Progo Regency is 8.83 years, up from 8.66 years in 2019, or in other words, the average population attends 1-2 grades of SMP. In 2021, the RLS in Kulon Progo Regency is predicted to increase to 8.92 years. Then it continues in 2022 where the RLS of Kulon Progo Regency will consistently increase again at 9.01 years. Until 2024, the RLS for Kulon Progo Regency is predicted to be 9.17 years. If you look at the graph, the RLS growth line is not very significant. As for HLS, it is predicted that in 2020 it will also increase from 14.25 years in 2019 to 14.51 years. In 2021 it will increase again to 14.63 years. Until 2024, the HLS of the Kulon Progo Regency is 14.86. The HLS growth graph tends to be similar to RLS. There was growth, although not very significant.

From the calculation of all the variables that make up the Human Development Index (HDI), the HDI figure in Kulon Progo Regency is estimated to continue to increase until 2024. In 2020, the HDI of Kulon Progo Regency is at 74.68, an increase of 0.24 from 2019 of 74. , 44. Then it will increase to 75.17 in 2021. Furthermore, in 2022 it will again increase to 75.65. Until the end of 2024, the IPM of the Kulon Progo Regency will increase to 76.52 .

The average increase in HDI in the 2020-2024 period was 0.55. Even though the HDI value has increased, growth in 2020 tends to slow down compared to the previous and projection years. This slowdown is influenced by a decline in expenditure per capita of the population in 2020. Meanwhile, the other three indicators are relatively more stable because they are not too affected by the Covid-19 pandemic case. 


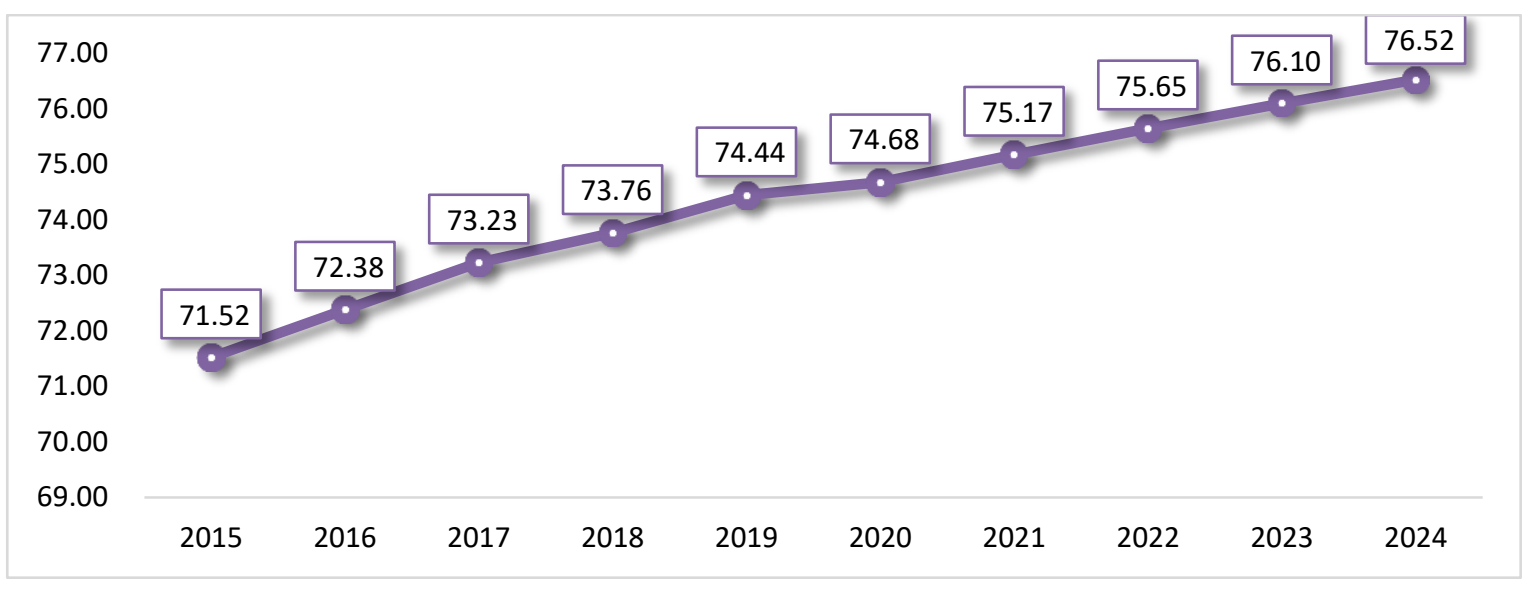

Figure 1.

Kulon Progo District Human Development Index (HDI) 2015-2019 and 2020-2024 Projection.

Meanwhile, the health aspect uses the Life Expectancy Rate (AHH) indicator. AHH is the average number of years a person will live. Several factors can influence AHH such as the achievement of health programs from the government, clean and healthy behavior for the community, education level, health facilities, and community income levels. The higher the $\mathrm{AHH}$, the better the quality of public health.

In 2020, AHH Kulon Progo Regency amounted to 75.26 years, increasing from 75.20 in 2019. Then increasing to 75.33 in 2021. Continuing in 2022 which also increased to 75.40. It is predicted that by 2024, AHH of Kulon Progo Regency will be 75.54 years. Kulon Progo Regency Government itself has made several innovations since 2015. One of them is the use of SMS Gateway technology, early detection, and prevention of malaria transmission, early detection of high risk (risk) maternal neonatal, online MPS monitoring of high-risk pregnant women to reduce cases of death. mothers and babies in Kulon Progo Regency.

Regarding the public health safety net through the BPJS, it also continues to be optimized. Based on BPJS Health data until December 2019, Universal Health Coverage (UHC) or the coverage of community members who have health insurance in the Kulon Progo Regency is still around $91.7 \%$. Meanwhile, to reach UHC, coverage of residents who have a guarantee must reach a minimum of $95 \%$. For this reason, the Kulon Progo Regency Government will prioritize the achievement of UHC by increasing financing for JKN participants who are registered by the government.

\section{CONCLUSION}

The direction of economic policy in the Kulon Progo Regency should focus on efforts to reduce poverty, unemployment, and economic inequality in society. The agrarian lifestyle that still dominates the economic activities of the community should ideally be maintained and there is a need for protection from the government so that people do not feel the impact due to changes towards industrialization. The following are some policy recommendations that can be offered to achieve inclusive economic growth in Kulon Progo Regency, including encouraging economic growth and improving the quality of human resources.

1. Improving the quality of prospective workers, especially in mastering technology and various types of competencies according to market needs. 
2. Implementing the 12-year compulsory education program and strengthening character-based education through gradually fulfilling the need for infrastructure and improving the quality of teaching staff.

3. Improve the quality of human resources in Kulon Progo Regency, especially in the application of information technology in various fields to support life-related to Industrial Revolution 4.0.

4. Increasing human resources with mastery of science and technology, skills and entrepreneurship in preparing people in all sectors to face the challenges of globalization and free markets.

\section{ACKNOWLEDGEMENT}

The author would like to thank Sinergi Visi Utama Consulting for Data and theoretical review for this manuscript. The Kulon Progo Regency for data supporting, information related to a real condition, and financial support.

\section{REFERENCES}

Breunig, Robert, and Omer Majeed. 2020. "Inequality, Poverty, and Economic Growth." International Economics 161: 83-99. https://doi.org/10.1016/j.inteco.2019.11.005.

Chu, Lan Khanh. 2020. "Financial Structure and Economic Growth Nexus Revisited." Borsa Istanbul Review 20(1): 24-36. https://doi.org/10.1016/j.bir.2019.08.003.

Croes, Robertico, Jorge Ridderstaat, and Valeriya Shapoval. 2020. "Extending Tourism Competitiveness to Human Development." Annals of Tourism Research 80(December 2018): 102825. https://doi.org/10.1016/j.annals.2019.102825.

Gupta, Rajeev, R K Dhamija, and Kiran Gaur. 2020. "Epidemiological Transition of Covid19 in India from Higher to the Lower HDI States and Territories Implications for Prevention and Control." MedRxiv (March): 1-16. http://medrxiv.org/cgi/content/short/2020.05.05.20092593.

Long, Xinyi et al. 2020. "Sustainability Evaluation Based on the Three-Dimensional Ecological Footprint and Human Development Index: A Case Study on the Four Island Regions in China." Journal of Environmental Management 265(March).

Maciel, Jacques Antonio Cavalcante, Igor Iuco Castro-Silva, and Mariana Ramalho de Farias. 2020. "Initial Analysis of the Spatial Correlation between the Incidence of Covid-19 and Human Development in the Municipalities of the State of Ceará in Brazil." Revista Brasileira de Epidemiologia 23: 1-17.

Maradana, Rana Pratap, et al. 2019. "Innovation and Economic Growth in European Economic Area Countries: The Granger Causality Approach." IIMB Management Review 31(3): 268-82. https://doi.org/10.1016/j.iimb.2019.03.002.

Martins, Nuno Ornelas. 2020. "Human Development: Which Way Now?" New Political Economy 25(3): 404-18. https://doi.org/10.1080/13563467.2019.1598961.

Osher, David, et al. 2020. "Drivers of Human Development: How Relationships and Context Shape Learning and Development1." Applied Developmental Science 24(1): 6-36. https://doi.org/10.1080/10888691.2017.1398650. 
Palomino, Juan C., Juan Gabriel Rodriguez, and Raquel Sebastian. 2020. "Wage Inequality and Poverty Effects of Lockdown and Social Distancing in Europe." SSRN Electronic Journal 44(0).

Ranasinghe, Ruwan, Chandi Karunarathna, and Jayathree Pradeepamali. 2020. "After Corona (COVID-19) Impacts on Global Poverty and Recovery of Tourism Based Service Economies: An Appraisal." SSRN Electronic Journal 1 Mei 2020(2): 1-15.

$\mathrm{Xu}$, Yunfu, and Aiya Li. 2020. "The Relationship between Innovative Human Capital and Interprovincial Economic Growth Based on Panel Data Model and Spatial Econometrics." Journal of Computational and Applied Mathematics 365: 112381. https://doi.org/10.1016/j.cam.2019.112381.

Yang, Zhenshan, and Yinghao Pan. 2020. "Human Capital, Housing Prices, and Regional Economic Development: Will 'Vying for Talent' through Policy Succeed?" Cities 98(December 2019): 102577. https://doi.org/10.1016/j.cities.2019.102577. 